\title{
The Scenario for Slum Handling in Kelurahan Kandai Kendari City
}

\author{
Joko Tri Brata ${ }^{1}$, Heber Heber ${ }^{2}$, Arisandi Sapri ${ }^{3}$ \\ \{joko_tribrata@yahoo.co.id ${ }^{1}$, he.ber@ymail.com², arisandisapri@yahoo.co.id ${ }^{3}$ \} \\ ${ }^{1}$ University of Southeast Sulawesi, Indonesia \\ ${ }^{2}$ Staff in PUPR Ministry, Indonesia \\ ${ }^{3}$ The City of coordinator KOTAKU Kendari, Indonesia
}

\begin{abstract}
Indonesia experiences high urban population growth, population growth has implications for increasing settlements, decent and affordable housing needs, as well as basic service needs and adequate settlement management systems, which have implications for the level of density and slums in urban areas. This type of research is a description, with research methods using a pattern of research phenomena, with research analysis combining the description of slums and technical directions for handling. Analysis to answer the first objective research, by analyzing qualitatively using the triagulation method. For the second problem, a number of scenario assignments relate to the slum handling pattern based on the technical handling of slums. The deepening of the research discussion involved experts from various universities in the Kendari City and special experts on slum handling, this form was repeated and also with sufficient frequency to ensure the reliability and accuracy of the data that had been obtained. The results of the study explain that the scenario of improving the quality of slum settlements in Kandai Village is done by efforts with a restoration pattern; rejuvenation; and resettlement which is formulated in an integrated manner by planning to improve the quality of slums, as well as by establishing joint rules.
\end{abstract}

Keywords: Slum, Handling Scenario.

\section{Introduction}

Housing and settlements are one of the basic human needs and are important factors in increasing human dignity and quality of life. Housing and settlements are also part of national development that needs to be continuously improved and developed in an integrated, directed, planned and sustainable manner [1].

In the past forty years, Indonesia experienced a high urban population growth, the population growth rate in the city reached an average of $2.75 \%$ every year and it is estimated that by the end of 2025 there will be around $60 \%$ of Indonesia's population living in cities [2]. The population growth has implications for increasing settlements, the need for decent and affordable housing, as well as basic service needs and adequate settlement management systems [3].

The main problem related to the handling of slums is the description of slum areas [4] and the second problem by establishing slum handling scenarios that are integrated with the patterns of life of the surrounding communities, so that the writer is encouraged to describe this study as a scenario for slum handling in the Village area [5].

The election of Kandai Village is to try to explore Irma Nurjannah [6], which explains that the Old Town of Kendari was once a city center, this area is also known as a port city 
which is one of the identities of the region. As a result of deteriorating environmental quality, namely decreasing regional aesthetics, historical buildings that began to disappear, spatial planning that did not meet requirements, community economic activities began to decrease, and the absence of city parks, so that the city was considered a dead city, so the selection of handling slums the one in Kandai Village which is also the Old City of Kendari (Irma called it the Old City), is very appropriate.

\section{Regional Overview}

The slums in Kendari District in 2014 were 50.8 hectares and according to the Mayor's Decree Mayor Kendari Decree Number 389 of 2016, the area of the slum was 58, 51 hectares. From these data, it can be seen that Kandai Village has a slum area of 12 hectares in 2014 and increased to 13.82 hectares according to the 2016 decree. Where if this slum area is not handled well, the assumption of the City of Mati will be increasingly prominent in this region [7].

Table 1. Data on the Area of Slum in Kendari District

\begin{tabular}{ccccc}
\hline \multirow{2}{*}{ NO. } & \multirow{2}{*}{ Sub District } & \multirow{2}{*}{ Kelurahan } & \multicolumn{2}{c}{ Width of Slum Area (HA) } \\
\cline { 3 - 4 } & & & SK 2014 & SK 2016 \\
\hline \multirow{2}{*}{ KENDARI } & Purirano & 4,3 & 4,72 \\
& & Mata & 2,5 & 8,6 \\
& Mangga Dua & 2,5 & 2,23 \\
& Kassilampe & 6 & 4,88 \\
& Kendari Caddi & 5 & 5,29 \\
& Kandai & 12 & 13,82 \\
& Kampung salo & 8 & 3,35 \\
& Jati Mekar & 5 & 10,8 \\
& Gunung Jati & 5,5 & 5,29 \\
\hline
\end{tabular}

Data Source : Kendari City, Slum Area Determination Letter, 2017 [7].

\section{Research Method}

This study is classified as a type of description research [8], so in used which tend to use research patterns to describe phenomena [9] and try to combine by looking at the description of slums [10].

Answering the objectives of the first research relating to the description of the researcher will analyze it qualitatively, by describing it based on the documentation material from the results of previous research and answering the problem with the Triagulation method. For the second problem, to establish a scenario that connects with the slum handling pattern based on the technical handling of slums, starting from the activity of analyzing, designing, evaluating, and revising to the desired destination.

\section{Results and Discussion}

The results of the study showed that the handling of slums in Kandai Village was carried out by using the technical pattern of standardized slum handling [10], namely; (1) Restoration 
and (2) Rejuvenation, and the use of handling patterns according to common rules. In the first part the researcher describes the application of technical standards for handling;

\section{Technical Handling Standard}

\subsection{Restoration}

Restoration of slums and slum settlements is applied based on the level of repairs and / or rebuilding needed. The need for repairs and/or rebuilding slums and slums is determined by the local government together with the community. Restoration of slums and slum settlements can be carried out by the Government, regional government, and / or by the community independently depending on the severity of the improvements that must be made and based on other considerations.

Restoration activities carried out by regional governments are carried out by authorized agencies/agencies such as the Housing Agency, Public Works Agency and other related agencies. The implementation of restoration activities with self-help, must be facilitated by the Government and / or local government. Restoration can be in the form of repairs to buildings, infrastructure, facilities, and/or public utilities that are carried out without fundamental reform and are of a partial nature.

In this form of handling generally there are not too many fundamental changes, apart from the improvement in the form of service and the physical condition of infrastructure, facilities and residential buildings, with the following types of restoration ;

\subsubsection{Revitalization of residential areas}

It is a type of handling to improve the quality of residential areas through improving environmental quality, without causing significant changes from the physical structure of the settlement area. This activity aims to improve and encourage the regional economy by utilizing existing existing facilities and infrastructure, improving the quality and capabilities of infrastructure and facilities through improvement and improvement programs without demolition.

In this activity, the procurement of new infrastructure and facilities is needed without changing the existing structure and optimally utilizing the previous building.

\subsubsection{Rehabilitasion}

It is a type of treatment that aims to restore the condition of the physical components of residential areas that have suffered deterioration in conditions or degradation, so that they can function again initially, for example repairing road infrastructure, clean waterways, drainage, and others.

\subsubsection{Renovation}

It is a type of handling by making changes in part components of the settlement (infrastructure and facilities) with the aim of the component being able to adapt and accommodate new functions. The general form is to improve the quality of these components according to new requirements. Which includes renovation;

- Adjustment of space utilization and improvement of infrastructure / utility systems and adjusting the direction of buildings

- Building size (building adjustments) to suit the demands of handling needs

- Space Orientasion. 


\subsubsection{Reconstrucsion}

It is a type of handling that aims to restore conditions (quality and function) and increase the components of settlements into their original conditions, both requirements and uses. In this case there is no concern about the consequences that arise due to changes in the size and shape of the component.

\subsubsection{Preservasi}

It is a type of handling carried out with the aim of maintaining residential components that are still functioning properly and preventing damage. As a control function, preservation can be done by affirmation through the rules of space and building utilization (KDB, KLB, GSB, GSJ, IMB, etc.). The nature of this handling tends to be more towards preventing the emergence of slums, so often these efforts are carried out together with restoration, rehabilitation and reconstruction.

\subsection{Rejuvenation}

Rejuvenation by rebuilding housing and settlements through comprehensive arrangement including housing and infrastructure, facilities and public utilities for housing and settlements. The implementation of rejuvenation must be carried out by first providing a place of residence for affected communities by meeting the applicable technical norms and standards.

Rejuvenation is carried out by the Government and regional governments in accordance with their authority by involving the role of the community and being applied to slum housing and slum settlements that stand on land which in the RTRW is intended for settlements.

Rejuvenation is applied to slums which are structurally and economically irreversible, so that they cannot be handled only by physical improvement and improvement. Structurally bad conditions can encourage the creation of inefficient and optimal spatial use in accordance with the functions specified. Slums that get treatment are generally characterized by ;

- There is no good clarity on the pattern / structure of environmental infrastructure;

- There is no clarity about the suitability of the spatial utilization pattern;

- The economic structure has very bad conditions because it is not supported by the abilityof economic development in residential areas;

- Can not adapt to the surrounding area.

Overall the condition of the area does not reflect the maximum utilization of functions in accordance with the potential of the land. Rejuvenation is mandatory for slums and slums with classification :

- Severe weight, and

- Legal land status.

This form of handling is generally carried out with fundamental changes. Therefore, this handling has the consequence of changing the pattern of space utilization, both in composition, component, quantity and function. This leads to new procurement patterns that are more prominent than quality improvement and improvement, with the following types of rejuvenation;

\subsubsection{Renewal}

It is a type of handling that is comprehensive by dismantling segaian or all components of the settlement, then structurally changing and rebuilding on the same land. The aim is to obtain optimal land use values in accordance with the potential of the 
land, and are expected to provide economic added value and new vitality. The consequences of this technical form of handling are: (a) Land consolidation, (b) Land readjustment, and (c) Land sharing, combination of residential and commercial land use.

The characteristics of slums that are handled, are: (a) The overall layout is not possible to develop and No longer suitable for accommodating new types of activities, (b) Poor accessibility, insufficient space and can no longer be expanded, the organization, (c) Space and poor functional relationships, and (d) The condition of the building is very bad and not suitable for use, because of the inability to serve functions properly.

\subsubsection{Redevelopment}

It is an effort to restructure a slum area by first demolishing facilities and infrastructure in part or all of the areas that have been declared unable to be maintained. Structural changes and land allotments and other development provisions governing new development (KLB, KDB, GSB, etc.) usually occur.

\subsubsection{Restorasion}

It is a type of handling to restore the condition of a slum settlement to its original condition in accordance with the correct requirements, eliminating additional or emerging components and then re-establishing the settlement elements that have been lost without adding new elements.

To complete the standard technical handlers of the Ministry of Public Works and Public Housing, in Kandai Village also conducts community consultations to deal with the slum conditions mentioned in the following illustration;

\section{Plan For Joint Rules}

In general, the joint regulatory substance in Kandai Village, agreed upon the reference proposal to become a Joint Rule and in accordance with the activity plan prepared in the Settlement Environmental Planning document, namely: Environment and Spatial Planning, Housing and Buildings, Facilities and Infrastructure, Economic Development, Public Services and Institutional fields. In each of these areas the division is described in more detail.

his joint rule is a follow-up of the Housing Settlement Plan (RPLP) document in Kandai Village. The rules that exist in the community are related to social, economic, environmental issues formulated and agreed upon in accordance with local policies (local wisdom) as a guide in managing the environment, society, and activities of the community of Kandai Village.

\subsection{Road Environment and Drainage}

\section{Factual Condition}

Environmental roads are mostly damaged, perforated, cracked and still in the form of soil

- Most road shoulders do not have drainage channels / drainage;

- Although there is a narrow and narrow land channel;

- No street lighting yet (PJU);

- Roads around residential areas are partly narrow, so they do not have convenient access, and do not have drainage channels; 
- Environmental road conditions are inadequate;

- Slum environmental conditions due to the absence of connecting channels such as drainage and culverts.

\section{Ideal Conditions}

- The existing road is built based on user comfort and safety;

- Roads that are supported by other facilities (drainage lines and street lighting);

- The width of the residential neighborhood is at least $150 \mathrm{~cm}$;

- Environmental roads are made so that they are comfortable to use.

\section{Joint Rules Agreed}

- $\quad$ Land for Road-Owned Space is available;

- Oriented to regional development;

- Connecting activity centers (residential settlements);

- Meet technical standards for road and functional infrastructure;

- Types of Road Construction that can be chosen to be carried out include concrete rebate roads and paving blocks;

- In the form of a maintenance team and manager of infrastructure buildings;

- If there is physical damage, the maintenance team and managers and residents as users / users must be responsible;

- There is a periodic review (monev) from the Kelurahan and regional government to check the condition of the infrastructure that has been built.

\subsection{Sewerage Drain (SPAL)}

\section{Factual Condision}

- $\quad$ The sewerage system is not integrated;

- Some tertiary drainage in the area does not function properly due to piles of garbage and heaps of building materials;

- There is no drainage channel in the RT01 / RW02 area in the hilly area;

- Sewerage of household waste water directly into the environmental drainage can cause odor.

\section{Ideal Condision}

- There is management of household waste, household sewage channels are channeled to septic tanks and if there is still available land in the residential area infiltration wells are made to maintain groundwater conditions and environmental pollution;

- Channels are closed by concrete plates to prevent waste from entering. The concrete plate must have an inlet so that rainwater can enter the channel.

\section{Joint Rules Agreed}

- Built according to shared needs, plans and technical quality;

- No change in function;

- Residents must maintain and utilize the drainage channel as well as possible (drainage channels in clean condition from garbage);

- Waste water flows in the channel; 
- A team of maintenance and management of the Drainage / Spal channel was formed

- If there is damage to the maintenance team and managers and residents as users / users, they must be responsible;

- There is a periodic review of the Kelurahan and regional government to check the condition of the drainage / spal channels that have been built;

- Provision of sanctions to anyone who violates the rules, especially littering, so that the community knows the importance of forgiving the drainage channel.

\subsection{Waste Factual Condition}

- People generally dispose of garbage in open / empty land;

- Some residents manage waste by burning it;

- Lack of awareness from area residents prioritizing the importance of environmental hygiene;

- Waste collection and disposal systems and transport of existing waste are ineffective.

- The high amount of waste production in dense residential areas is supported by the increasing population growth in the region;

- Difficulty in providing land for trash / TPS, the old paradigm of waste management relies on the process (collect-take-trow away);

- There is no effective waste management.

\section{Ideal Condition}

- The existence of waste management and handling is integrated with the Environmental Service and caring groups;

- Provision of bins and polling stations in residential areas;

- Management of waste 3R (Reduse, Reuse and Recycle) or sorting, processing and recycling.

\section{Joint Rules Agreed}

- Every resident in a residential area is prohibited from littering;

- Making regulations regarding waste laws in the Kandai Village environment;

- Every citizen of Kandai Village must obey the rules that have been made;

- The community is ready to maintain the cleanliness of the environment and jointly conduct environmental clean-up (community service during Friday clean);

- The community disposes of garbage in the trash that will be prepared by separating organic waste and inorganic waste;

- Communities are ready to take part in counseling to explore knowledge about waste management such as learning to do composting, biopori and applying it in the environment;

- Communities form groups of non-governmental organizations to manage waste management;

- Communities are prepared to pay regular waste management fees as agreed upon;

- Provision of sanctions to anyone who violates the rules, especially littering. 


\section{Criteria and Location Scenarios for Quality Improvement of Slum Settlements}

Based on the results of the Swadaya Mapping there are 10 RTs that are priority locations for slum handling, namely RT01 / RW01, RT01 / RW02, RT01 / RW03, RT01 / RW04, RT01 / RW05, and RT01 / RW06, RT02 / RW01, RT02 / RW02, RT02 / RW02, RT02 / RW04 RW03, RT02 / RW04, RT02 / RW05, RT02 / RW06, RT03 / RW02, RT03 / RW03, RT04 / RW02, RT04 / RW03. The criteria for selecting priority locations in Kandai Village can be seen in the following table:

Tabel 2. Location Criteria

\begin{tabular}{|c|c|c|}
\hline No. & Criteria / Indicator & Parameter \\
\hline A. & Psycal & \\
\hline 1 & Building Order & $49 \%$ Residential buildings have order \\
\hline 2 & Building Density & Surface area has a low density ( 15 units / ha) \\
\hline 3 & Feasibility of Buildings & $82 \%$ Residential buildings have a floor area of $27.2 \mathrm{~m} 2$ \\
\hline \multirow[t]{2}{*}{4} & \multirow[t]{2}{*}{ Environmental Accessibility } & $\begin{array}{l}75 \% \text { Residential buildings have roof, floor, wall } \\
\text { conditions according to technical requirements } \\
50 \% \text { Settlement areas are served by a minimum } \\
\text { environmental road network }\end{array}$ \\
\hline & & $\begin{array}{l}36 \% \text { of the condition of the road network in residential } \\
\text { areas has adequate minimum quality }\end{array}$ \\
\hline \multirow[t]{2}{*}{5} & \multirow[t]{2}{*}{ Environmental Drainage } & $100 \%$ Settlement areas do not have puddles / floods \\
\hline & & $\begin{array}{l}75 \% \text { The condition of the drainage network at the } \\
\text { settlement location has adequate minimum quality }\end{array}$ \\
\hline \multirow[t]{3}{*}{6} & \multirow[t]{2}{*}{$\begin{array}{l}\text { Drinking / Raw Water } \\
\text { Services }\end{array}$} & $\begin{array}{l}85 \% \text { of the community is served Drinking Water Facilities } \\
\text { for drinking, bathing and washing (piping or non-piping } \\
\text { that is properly protected) }\end{array}$ \\
\hline & & $\begin{array}{l}61 \% \text { of the community fulfilled the needs of drinking } \\
\text { water, bathing, washing (minimum } 60 \text { liters / person / day) }\end{array}$ \\
\hline & \multirow{3}{*}{ Waste Water Management } & $\begin{array}{l}97 \% \text { Communities have access to family toilets / shared } \\
\text { toilets (s KK / latrine) }\end{array}$ \\
\hline \multirow[t]{2}{*}{7} & & $\begin{array}{l}76 \% \text { Shared family toilet / toilet according to technical } \\
\text { requirements (has a goose neck toilet connected to a septic } \\
\text { tank) }\end{array}$ \\
\hline & & $\begin{array}{l}100 \% \text { Separate sewerage for households with } \\
\text { environmental drainage channels }\end{array}$ \\
\hline 8 & Solid waste management & $\begin{array}{l}70 \% \text { solid waste management Domestic household waste } \\
\text { in residential areas is transported to TPS / TPA } 2 \text { times a } \\
\text { week }\end{array}$ \\
\hline 9 & Safeguarding & $\begin{array}{l}0 \% \text { Fire Hazards Settlement areas have fire protection } \\
\text { infrastructure / facilities }\end{array}$ \\
\hline B. & Non Physical & \\
\hline \multirow[b]{2}{*}{1} & \multirow{3}{*}{$\begin{array}{l}\text { Legality of building } \\
\text { establishment } \\
\text { Population Density }\end{array}$} & $38 \%$ Residential buildings have IMB \\
\hline & & $76 \%$ Residential building has SHM / HGB / Letters \\
\hline 2 & & $59 /$ ha \\
\hline 3 & Livelihoods & $\begin{array}{l}4 \% \text { The main livelihoods of households are trade / } \\
\text { services (teachers, health workers, hotels, etc.) }\end{array}$ \\
\hline 4 & Electric Power & $\begin{array}{l}58 \% \text { of the majority of households use } 900 \text { watts of } \\
\text { electricity (household units) }\end{array}$ \\
\hline 5 & Health Service Facilities & $\begin{array}{l}65 \% \text { Majority of Households in residential areas use } \\
\text { health facilities in Puskesmas / Pustu (household units) }\end{array}$ \\
\hline
\end{tabular}




\begin{tabular}{cll}
\hline No. & \multicolumn{1}{c}{ Criteria / Indicator } & \multicolumn{1}{c}{ Parameter } \\
\hline 6 & $\begin{array}{l}\text { Educational Service } \\
\text { Facilities }\end{array}$ & $\begin{array}{l}47 \% \text { The majority of households have } 9 \text { years of } \\
\text { compulsory education (SD-SMP) have access to basic } \\
\text { education in the same kelurahan / subdistrict (household } \\
\text { unit) }\end{array}$ \\
\hline
\end{tabular}

Tabel 3. Strategy Formulation and Kelurahan Kandai Area Handling Program ;

\begin{tabular}{|c|c|c|c|}
\hline No. & Policy & & Strategi \\
\hline 1 & $\begin{array}{l}\text { Improving the quality of } \\
\text { residential and } \\
\text { environmental }\end{array}$ & $\begin{array}{l}1 \\
2\end{array}$ & $\begin{array}{l}\text { Repair of houses not suitable for low-income } \\
\text { communities in the deliniation area } \\
\text { Settlement environment }\end{array}$ \\
\hline \multirow{5}{*}{2} & \multirow{5}{*}{$\begin{array}{l}\text { Provision of adequate } \\
\text { settlement infrastructure }\end{array}$} & 1 & $\begin{array}{l}\text { Achievement of the target of } 100 \% \text { of drinking } \\
\text { water services for all residents of slum areas in } 2019\end{array}$ \\
\hline & & 2 & $\begin{array}{l}\text { Achieving a target of } 100 \% \text { access to domestic } \\
\text { wastewater proper sanitation by } 2019\end{array}$ \\
\hline & & 3 & $\begin{array}{l}\text { Construction of facilities for environmental drainage } \\
\text { infrastructure in all slums in } 2019\end{array}$ \\
\hline & & 4 & $\begin{array}{l}\text { Arrangement of environmental roads and bridges in } \\
\text { all slums in } 2019\end{array}$ \\
\hline & & 5 & $\begin{array}{l}\text { Provision of clean water facilities and infrastructure } \\
\text { in all slums in } 2019\end{array}$ \\
\hline \multirow[t]{2}{*}{3} & \multirow{2}{*}{$\begin{array}{l}\text { Provision and } \\
\text { management of } \\
\text { environmentally sound } \\
\text { settlement infrastructure }\end{array}$} & 1 & $\begin{array}{l}\text { Provision and management of settlement } \\
\text { infrastructure to prevent and anticipate a decrease in } \\
\text { environmental carrying capacity; }\end{array}$ \\
\hline & & 2 & $\begin{array}{l}\text { Development and dissemination of disaster } \\
\text { mitigation and adaptation management }\end{array}$ \\
\hline
\end{tabular}

\section{Conclusion}

There are 2 scenarios for improving the quality of slum settlements in Kelurahan Kandai. There are 2 patterns to improve the quality of slum settlements that are used, namely by efforts to deal with the pattern of restoration with technical management in the form of regional revitalization; Rehabilitation (repair); Renovation and Reconstruction.

Meanwhile for settlement rejuvenation patterns carried out by activities in the form of Renewal (rejuvenation); Redevelopment (rearrangement), and; Restoration (to restore the condition of a settlement).

To complement technically the handling of slums and Kandai Village, a joint arrangement in the form of a participatory agreement on the location of the slum location agreed upon by the residents was carried out. The Joint Rules aim to formulate and legalize rules in society to realize development towards a healthy, green, clean, productive and sustainable residential environment in accordance with the mutually agreed mission.

This research still requires deepening related to the obstacles faced by the community in terms of handling in a participatory manner, in relation to the location of the area being handled is an urban area that has heterogeneous characteristics of citizens. 


\section{References}

[1] Ariyanto, Asep, (2015). Strategi Penanganan Kawasan Kumuh Sebagai Upaya Menciptakan Lingkungan Pemukiman Yang Sehat di Kota Pangkapinang, Jurnal Perencanaan Wilayah Kota, Unisba Bandung, Volume 2, Halaman 11-37, 2015.

[2] Kementrian Pekerjaan Umum dan Perumahan Rakyat (2018), Paparan Dirjen Cipta Karya dalam Rapat Teknis Penanganan Kumuh, 2018.

[3] Peraturan Pemerintah Nomor 14 Tahun 2016, tentang Penyelenggaraan Perumahan dan Kawasan Permukiman, 2016.

[4] Rindroyono, 2013. Pemukiman Kumuh dan Budaya Masyarakat, Jurnal PWK ITB Bandung, Volume 4 Tahun 2013.

[5] Fitria, Niken dan Rulli Pratiwi Setiawan, Identifikasi Karakteristik Lingkungan Permukiman Kumuh di Kelurahan Kapuk, Jakarta Barat, Jurnal POMITS, Volume 3 Nomor 2, ISSN: 2337-3539 (2301-9271 Print), 2014.

[6] Nurjannah, Irma, Kajian Konsep Penataan Kawasan Kota Lama Kendari, Berdasarkan Identitas dan Citra Kota, Jurnal Langkau Betang, Volume 4 Nomor 2 Tahun 2017,.

[7] Dokumen RPLP Kota Kendari, 2017.

[8] Sugiyono. 2013. Metode Penelitian Pendidikan Pendekatan Kuantitatif Kualitatif, dan R\&D Bandung: Alfabeta, 2013.

[9] Lexy J. Moleong. Metodologi Ppenelitian Kualitatif, Bandung: Remaja Rosdakarya, 2017.

[10] Undang-Undang Nomor 1 Tahun 2011, Tentang Perumahan dan Kawasan Permukiman, 2011. 